\title{
O LUTO E A HiSTÓRIA EM DE MIM JÁ NEM SE LEMBRA, DE LUIZ RUFFATO ${ }^{1}$
}

\author{
Marcos Vinícius Lima de Almeida
}

\section{A ALEGORIA DO ESPECTRO: O REI NUM ESPELHO}

Nosso tempo está desnorteado (Shakespeare, Hamlet, Ato I, Cena V)

A cena é conhecida: no reino da Dinamarca, durante a troca das sentinelas noturnas, Marcelo pergunta a Bernardo se "essa noite a coisa apareceu de novo". ${ }^{2}$ A coisa, no caso, é um espectro, que vem rondando o castelo. Horácio desdenha dos guardas: "Ora, ora, não vai aparecer". Mas então, quando a estrela a oeste do polo ilumina a mesma parte do céu da noite anterior, uma figura fantasmagórica, com a mesma aparência do falecido rei, surge no céu, sob o rumor dos sinos do castelo. "Não te parece o rei? Repara bem”, diz Bernardo. "É igual”, diz Horácio, "estou trespassado de espanto e medo". A despeito da insistência das sentinelas para que o

1 Este artigo é resultado de um trabalho maior, que envolve meu projeto de pesquisa no mestrado em Literatura e Crítica Literária na PUCSP, sob orientação da professora Dra. Annita Costa Malufe, com bolsa FAPESP, processo no 2016/04695-1. Agradeço ainda aos colegas do grupo de pesquisa $\mathrm{O}$ Narrador e as Fronteiras do Relato, no qual apresentei a primeira versão deste trabalho, em especial a Maria José Gordo Palo e à professora Maria Rosa Duarte de Oliveira, pelos estimulantes debates ao redor dos impasses da narrativa contemporânea e das noções de fantasma e espectro.

2 As citações da peça aqui usadas foram extraídas - e levemente adaptadas para prosa, conforme a necessidade - da tradução de Millôr Fernandes, e podem ser facilmente encontradas na leitura do primeiro ato, Cena I - V (SHAKESPEARE, 1997). 
espectro fale e esclareça o motivo de profanar os limites entre o mundo dos vivos e dos mortos, impera o mais absoluto silêncio. Ao especular sobre a natureza da criatura e sua semelhança com o falecido monarca, Horácio conclui que o fantasma é como "o rei num espelho".

Mas eis que a situação se agrava: o espectro surge pela segunda vez, na mesma noite, para o espanto dos soldados. E pela segunda vez o fantasma permanece em silêncio. Então desaparece misteriosamente ao cantar do primeiro galo, quando os primeiros fios de sol surgem no horizonte. Acompanhadas de Horácio, as sentinelas contam ao jovem Hamlet sobre as aparições. Hamlet resolve ir ele mesmo falar com o tal espectro, cuja aparência é igual à de seu pai. Na madrugada seguinte, postado no mesmo lugar e na mesma hora em que a criatura costuma se revelar, o jovem príncipe vê a cena com seus próprios olhos. $\mathrm{O}$ fantasma chama por Hamlet. Os dois se afastam e começam a conversar. "Fala", diz Hamlet, "estou pronto para te ouvir". "E também pra me vingar", diz o espectro, "depois de ouvir".

O espectro diz que está condenado a vagar durante a noite. Durante o dia, passa fome, no fogo, até que seus crimes tenham se transformado em cinzas. "Eu te revelaria uma história cuja palavra mais leve arrancaria as raízes da tua alma", diz o espectro. "Mas esses segredos do sobrenatural não são pra ouvidos feitos de carne e sangue”.

Exigindo vingança, o espectro revela que o motivo de sua morte não foi a picada de uma serpente no jardim: foi vítima de um assassinato, e o assassino agora está no trono. "Teu tio entrou furtivamente, trazendo, num frasco, o suco da ébona maldita, e derramou, no pavilhão de meus ouvidos, a essência morfética que é inimiga mortal do sangue humano", diz o espectro, que perdeu, ao mesmo tempo, a coroa, a rainha e a vida. Antes que o sol apareça no horizonte, o espectro se despede: "Adeus, adeus, adeus! Lembra de mim”.

O espectro, segundo Leyla Perrone-Moisés (2016, p. 150), é um morto mal enterrado, que volta para cobrar alguma coisa: é o passado que se recusa a morrer. A autora traz essa imagem do espectro das reflexões de Jaques Derrida (1994), cuja obra Espectros de Marx inaugura aquilo que o filósofo da desconstrução chama de espectrologia. O texto de Derrida é fruto de uma conferência cujo problema era a atualidade do pensamento de Marx, em voga naquele momento, o lugar do marxismo num mundo Pós-URSS e "pós-histórico" - como havia anunciado o então best seller 
dos anos 1990, Francis Fukuyama. Derrida recorre tanto à passagem do Manifesto ("um espectro ronda a Europa"), como ao fantasma do pai de Hamlet para fundar sua reflexão sobre os espectros. Na raiz da questão do espectro está a questão da justiça.

\begin{abstract}
Se me apreço a falar longamente de fantasmas, de herança e de gerações de fantasmas, ou seja, decertos outros que não estão presentes, nem presentemente vivos, nem para nós, nem fora de nós, é em nome da justiça. Da justiça onde ela ainda não está, ainda não está presente, aí onde ela não está mais, entenda-se, aí onde ela não está mais presente, e aí onde ela nunca será, não mais do que a lei, redutível ao direito. É preciso falar do fantasma, até mesmo ao fantasma e com ele... (DERRIDA, 1994, p. 11, grifos do autor).
\end{abstract}

A espectrologia de Derrida não se restringe exclusivamente ao campo do marxismo (PERRONE-MOISÉS, 2016, p. 151), tanto que Leyla Perrone usa esse quase-conceito em outro plano: para tratar de uma certa tendência naquilo que ela chama de literatura da "modernidade tardia" (isto é, a Literatura Contemporânea), que é em certa medida assombrada pela literatura "anterior", que a autora designa como "alta modernidade". A tese central é a de que as principais formas que a literatura contemporânea tem assumido são dependentes do passado. Isso se deve ao fato de que nossa época tem uma carga histórica gigantesca nas costas. Para a autora, os procedimentos como citação, reescritura, fragmentação, colagem, metaliteratura, ironia, "todas remetem à história e às obras desse passado" (p. 149). Ou seja, a produção contemporânea se faz, necessariamente, a partir de uma relação direta com discursos e formas pré-existentes. Isso explicaria, portanto, não apenas a recorrência de escritores contemporâneos em usar autores do passado como personagem, mas também a tendência das formas literárias da atualidade em tencionar, necessariamente, as formas que as antecederam. No próprio romance de Ruffato, que se apropria da forma epistolar, esse procedimento acontece. Em outros termos: a própria forma epistolar pode ser entendida como um espectro que assombra o romance.

Na espectrologia de Derrida (1994), há três tipos de seres fantasmais: spectre, fantôme e revenant. A diferença, esclarece Leyla Perrone-Moisés (2016, p. 152), é que enquanto espectro e fantasmas são sinônimos, revenant seria "aquele que volta", assombra, mas não pode ser visto, apenas pressentido.

Esta Coisa que não é uma coisa, essa Coisa invisível entre seus aparecimentos, não a veremos mais em carne e osso quando ela reaparecer. Essa Coisa olha para 
nós, no entanto, e vê-nos não vê-la mesmo quando ela está aí. Uma dissimetria espectral interrompe toda especularidade. Ela dessincroniza, faz-nos voltar à anacronia. A isso chamamos efeito de viseira: não vemos quem nos olha (DERRIDA, 1994, p. 22, grifo do autor).

"O espectro não é nem o morto nem o vivo; nem o corpo, nem a alma; nem o dentro, nem o fora, nem o presente, nem o passado" (SKINNER, 200o, p. 65). Os espectros nos olham, portanto, de um tempo anacrônico. São seres do passado. Mas sua imaterialidade perfura o tempo: estão fora daquele seu tempo de origem - onde morreram, seu cadáver está lá, mal enterrado, mas não o espectro. Ele está também nesse agora, nesse outro tempo, o presente, dos vivos, sem conseguir se adequar completamente a esse tempo. Está e não está. Os espectros não pertencem a lugar nenhum. Sua presença diante de nós é uma potência desestabilizadora.

Há três maneiras de lidar com o espectro: 1) fazer o trabalho do luto, colocando o espectro num túmulo, preciso e identificável; 2) nomear o espectro, torná-lo conhecido, falar com essa voz; 3) trabalhar o espectro e fazer dele um espírito, naquela concepção de Valéry, espírito no sentido daquilo que tem o poder de transformação e, assim, tirar algo novo do espectro e transmiti-lo ao futuro (PERRONE-MOISÉS, 2016, p. 152).

No livro de Luiz Ruffato (2016), De mim já nem se lembra, como veremos logo a seguir, a potência do espectro se manifesta, principalmente, de duas formas: no trabalho do luto em relação à morte do irmão - com quem é preciso falar; como também nos rastros da Ditadura Civil-Militar. Passemos, pois, à leitura da obra.

\section{OS ESPECTROS DE RUFFATO}

O projeto literário do escritor mineiro Luiz Rufatto é marcado, ao mesmo tempo, por uma busca por novas formas de expressão e pela preocupação social materializada na narrativa. Não se trata, portanto, apenas de exercícios de linguagem. Forma e conteúdo são inseparáveis. Em Ficção brasileira contemporânea, o crítico e pesquisador Karl Erik Schollhammer (2009, p. 55) afirma que a obra de Ruffato se desdobra sob duas vertentes: o experimentalismo modernista e um realismo engajado. Em entrevista recente (RUFFATO, [s.d., s.p.]) o escritor mineiro explicita de maneira clara suas ambições literárias:3 "Eu tive dois problemas antes

3 Schollhammer usa também a fala do escritor, tomando por base uma outra entrevista, mas que apresenta a mesma ideia. Segundo o crítico, essa fala de Ruffato expressa "uma Remate de Males, Campinas-SP, v. 37 n. 1, pp. 429-447, jan./jun. 2017 
de começar a escrever", diz o escritor. "Um, era questão de conteúdo, que era mais clara”. Segundo o autor, sua origem - filho de uma lavadeira analfabeta e de um pipoqueiro semianalfabeto, além de ele mesmo ter trabalhado como torneiro mecânico e em outras profissões braçais despertou seu interesse pelo universo da classe média baixa. "Pra mim sempre foi muito claro que era esse o universo que eu queria tratar literariamente". Na mesma entrevista, Ruffato diz que o grande problema era como tratar disso: "Se eu fosse discutir isso usando a forma do romance burguês, eu estaria traindo o projeto em si. Por que o romance burguês, ele é criado, ele é inventado, ele é intuído para dar margem a uma visão de mundo da burguesia que estava surgindo no século XVIII, como a classe revolucionária. Pra mim, essa forma não dá conta de uma visão de mundo que não seja burguesa”. Essa busca pela forma se materializou no romance Eles eram muitos cavalos (2001), cujo recorte da cidade da metrópole expressa um universo fragmentado e instável, que se manifesta através de um discurso poético desestabilizado, uma espécie de imagem não visível da caótica São Paulo, que não reproduz nem imita, uma imagem de pensamento (SCHOLLHAMMER, 2009, p. 81).

De mim já não se lembra dá continuidade à poética de Ruffato. O livro foi publicado pela primeira vez em 2007, pela editora Moderna, numa série paradidática voltada à alfabetização de jovens e adultos. ${ }^{4} \mathrm{O}$ livro era classificado como literatura infanto-juvenil. A segunda edição, revista, ampliada e definitiva, conforme informa a folha de rosto, foi publicada pela Companhia das Letras, em 2016, e deixou de ter a categorização de infanto-juvenil. Tomamos essa edição como material de nossa reflexão.

\section{EXPLICAÇÃO NECESSÁRIA: A MORTE DA MÃE E O ENCONTRO DAS CARTAS}

Mudo, larguei-a desamparada, espectro flutuando no colchão (Ruffato, 2016, p. 15)

consciência lúcida quanto aos desafios expressivos" (SCHOLLHAMMER, 2009, p. 55). 4 "Escrito em 2007 para um programa de educação de jovens e adultos, De mim já nem se lembra está sendo republicado, em versão ampliada, no momento em que o país atravessa uma de suas crises mais profundas." (FREITAS, 2016). 
De mim já não se lembra está dividido em três partes. Naquilo que podemos chamar de prefácio, intitulado "Explicação necessária", o narrador, que tem o mesmo nome do autor, vai visitar a família em Cataguases, interior de Minas Gerais. Sua mãe falece e ele encontra a caixa de cartas do irmão, em 2001, mas só as abre em 2003. Na segunda parte, intitulada "As cartas", a narrativa é conduzida pelas próprias cartas de José Célio, endereçadas à mãe, as quais mostram um jovem torneiro-mecânico que se mudou para Diadema, no início dos anos 1970, e depois faleceu num trágico acidente de carro. A terceira parte, intitulada "Apêndice", é uma espécie de epílogo: trata-se de uma carta de Ruffato ao irmão, um acerto de contas, datada de 2008 , quando a morte deste completou 30 anos.

A narrativa começa, portanto, pelo meio. Cronologicamente, o tempo representado é 2001. A voz usa o tempo verbal no passado. Está, portanto, narrando dalgum ponto no futuro, em retrospecto. Essa primeira parte é narrada em primeira pessoa, por uma voz que tenta enfeixar o passado numa narrativa. Domesticá-lo. Uma memória que se faz presente, guiada pelo desejo de organizar, voluntariamente, o passado.

Mas, tão logo essa voz primeira começa a narrar, ela se duplica numa outra voz, que aparece em itálico, também em primeira pessoa, à medida que a narrativa avança. São flashbacks que irrompem no texto, de um outro tempo, anterior a esse tempo representado na narrativa: irrompem involuntariamente, desestabilizando, não obedecendo à vontade organizadora da primeira voz, à medida que uma lembrança éevocada. Essa voz é a lembrança dentro da lembrança: é a voz que encarna a perspectiva de Luizinho, o jovem Ruffato, que será também um personagem nas cartas que José Célio envia à mãe, na segunda parte do livro. Se essa voz irrompe do passado, involuntariamente, é porque há alguma questão não resolvida, alguma questão suspensa. Essa voz duplicada é o primeiro espectro.

Mesmo insistindo todos - eu, minha irmã, Luzimar, Soninha e meu pai -, somente em fins de março minha mãe acedeu em visitar um médico, o doutor Wesley, novato, mas já investido de certo renome. Ele ouviu suas queixas, Tenho nada não, vim porque o povo teimou, auscultou-a, indagou dos pregressos, requereu chapa do pulmão, exames de sangue, urina e escarro, ponderando a tuberculose que um dia carcomeu a saúde do meu pai. (A madrugada sonolenta espetava momentaneamente aos nossos passos, determinados os da minha mãe, erradios os meus. O ônibus da Viação Vitória nos abandonava em Juiz de Fora e apressávamos a outro que nos desembarcava em Santos Dumont, onde meu pai internaram no Sanatório Palmira. Um domingo por mês, o trajeto. Minha mãe presenteava-o com esperanças: eu, do lado de fora preso, avistava-o ao longe 
em meio às árvores, e, de cócoras, entretinha-me com formigas-cabeçudas, paquinhas e lagartixas.) (RUFFATO, 2016, p. 14, grifos do autor).

O trecho sem itálico, que abre o parágrafo, é a tentativa do narrador em organizar a lembrança num discurso narrativo. Contar os fatos, um depois do outro. Mas, ao evocar esse passado, um outro passado, explícito pelo uso do itálico, irrompe involuntariamente. É a perspectiva de Luizinho que aparece: o garoto "preso do lado de fora", entretido com "formigascabeçudas, paquinhas e lagartixas".

Em sete de setembro de 2001, uma sexta-feira, Ruffato está em Belo Horizonte, quando recebe a ligação da irmã, informando sobre o falecimento da mãe. Viaja para Cataguases, para o enterro.

\begin{abstract}
Antes de o coveiro assentar os tijolos que lacrariam a cripta, afastei-me barranco abaixo do triste e horrendo cemitério, e meu amigo Fernando Cesário me guiou para longe, asilando-me em seu sítio, na estrada Cataguases-Miraí.

Meus pés descalços chapinham - a água ou lama alcança o tornozelo - numa espécie de caverna tão escura, que, arregalados os olhos, não vejo minhas mãos imundas tateando as sombras. Teias de aranha lanham meu rosto, em locas guincham ratos famélicos, baratas voadoras esbarram em meu corpo nu. Algo me impele e adivinho que, à medida que avanço, desmoronam barrancos às minhas costas. O buraco se estreita e o ar escasseia, arrasto-me - lamurientas vozes orientam minha esperança. Minhas coxas fraquejam, as fontes palpitam, ardem os pulmões. Estranhamente não grito; esgana-me, parece a aflição. Súbito, os braços envolvem-me as pernas: estou pronto (RUFFATO, 2016, pp. 17-18, grifos do autor).
\end{abstract}

A imagem aqui é ainda mais forte e fica mais patente o caráter involuntário, expresso em um discurso indireto livre. Enquanto no trecho de abertura o narrador se afasta do cemitério, na lembrança involuntária (ou fantasia), ele penetra o interior da terra. Quer pegar esse mistério que é a morte, esse espectro dependurado nos nossos ombros desde aquele choro primeiro que anuncia a chegada ao mundo. Mas não dá para abraçar esse fantasma: ali ele encontra baratas, aranhas, falta de ar. E sua única esperança - essa fé precária diante de algo que ultrapassa nossas forças - é construída na miragem de vozes lamurientas, que nada dizem. Então os braços da morte o encontram. E ele se sente pronto para desaparecer.

A questão não resolvida em relação ao irmão fica explícita logo à frente nesse texto de abertura. Ruffato encontrou as cartas, em 2001, vagou com elas de mudança em mudança, mas não as abriu, não as leu. "Receava, embrenhado-me naquele deserto de episódios, afogar-me em traiçoeiras lembranças movediças? Talvez. Mas, mais comezinho, julgo 
que empurrava-me o orgulho provocado pelo ciúme" (RUFFATO, 2016, p. 21). Isso porque a mãe havia cuidado de preservar aquela memória do filho mais velho. E, na perspectiva do narrador, tal gesto "implicava renúncia e provação”. O efeito disso era que, nos diz Ruffato (2016, p. 22): ela, a mãe, "distraiu de mim, da minha irmã". O espectro desse ciúme o impedia de lidar com o luto, em relação ao irmão, mas também em relação à mãe e ao pai. São esses os fantasmas que assombram o narrador. Estão mortos, mas mal enterrados.

Ao abrir a correspondência em 2003, o narrador se dispõe a ler uma por uma, cuidadosamente, as cartas - cinquenta, ao todo - de seu irmão, José Célio, endereçadas à mãe. Cartas escritas nos anos 1970, mas que não terminaram de chegar. "Aqui reúno esse passado - modo de reparar meus mortos, que já pesam do lado esquerdo: meu irmão, minha mãe, meu pai, aqueles aos quais me reunirei um dia. A eles, este livro" (RUFFATO, 2016, p. 22).

Assim termina a "Explicação necessária": estamos diante de um livro, de uma escrita que não é outra coisa senão uma vã batalha ao redor da morte. Que tenta conjurar esses espectros do passado, também presentes, que atormentam o narrador: porque a própria morte é o mais traiçoeiro dos espectros. Olha-nos desde sempre, na imagem dos mortos que enterramos, mas também nessa morte sempre presente, pura potência, sempre por vir.

\section{As cartas: os espectros da Ditadura}

Já na folha de rosto que abre a segunda parte do livro, logo abaixo do título "As cartas", está escrito, em itálico, uma enigmática frase: "Para você, que já me esqueceu” (RUFFATO, 2016, p. 23). Quem disse isso? De quem é essa voz? Se endereça a quem?

Não é do narrador da primeira parte, que agora se afasta e se coloca na posição de leitor. O próprio lugar que essa folha de rosto ocupa é um lugar sem determinação: a folha de rosto não está na narrativa da primeira parte, tampouco pertence à narrativa das cartas de José Célio. Essa folha de rosto é um lugar de passagem, está fora do tempo: do tempo lembrado e do tempo da lembrança. É o lugar do espectro.

É por isso que podemos sugerir a hipótese de que essa voz que brota de forma involuntária (num procedimento similar àquela voz duplicada da primeira parte), essa voz espectral na folha de rosto é de José Célio, 
exigindo um acerto de contas. Mas não o José Célio das cartas, e sim um José Célio espectral, que habita a memória de Ruffato, o eu que narra.

Os mortos precisam ser lembrados, para então serem esquecidos. É exatamente assim que se comporta o espectro do rei morto: "Lembra de mim”. É a voz espectral de José Célio que dedica as cartas a Ruffato. A frase: "Para você, que já me esqueceu" é também uma cobrança. Uma outra forma de dizer: "Lembra de mim”, você que, afinal, De mim já nem se lembra. E essa dedicatória só poderá vir nesse agora espectral. Como se o próprio ato de encontrar as cartas (por acaso, ao mexer na estante), fosse provocado pela ação do fantasma: esse espectro esteve desde sempre aí, em potência, à espreita, exigindo uma resposta.

Como diz Benjamin (1987, p. 57, grifo nosso), em luminosa passagem, há algo de brutal nessas cartas que permaneceram muito tempo sem serem abertas: "são deserdados que perfidamente forjam uma quieta vingança por longos dias de sofrimento". Esse arquivo do passado, a carta guardada, opera ela mesma na lógica do espectro: recusa-se a morrer completamente, arma seu ardil de vingança.

Mas reler as cartas é também uma tentativa de reescrever esse passado. Organizar as cartas, dispô-las numa cronologia, é uma tentativa de ordenar aquele tempo outrora vivido, e também esse tempo vivido agora. Uma depois da outra, quem sabe assim o narrador possa inferir nessa disposição cronológica uma causalidade, algum tipo de necessidade intrínseca que talvez possa dar um sentido tranquilizador para sua vida.

Percorrer as cartas é, para o narrador, um processo de luto. Esse passado reunido tem a potência de libertá-lo, porque liberta o espectro que o assombra. É trabalhar o espectro, fazer dele um espírito, transformá-lo num tempo por vir. Embora as cartas sejam endereçadas à mãe, José Célio está sempre falando de Luizinho e da irmã. E é nessa travessia de leitura que Ruffato reencontra seu afeto, nessa relação conflituosa de admiração e ciúme do irmão. "Tinha muito tempo que eu não me sentia assim tão contente” (RUFFATO, 2016, p. 63), escreve José Célio, e, mais adiante, na mesma carta:

O Luizinho, conversei muito com ele. Teve um dia que nós ficamos sentados em cima da laje conversando e quando vimos já era noite. Ele está doido para entrar no Senai e ficou especulando como era a vida aqui em Diadema. Achei muito legal. Eu fico tranquilo, porque acho que ele está bem encaminhado. Graças a Deus (p. 63).

Em outro momento, o irmão escreve o seguinte: 
E fala para o Luizinho ir preparando porque nós dois vamos naquele salão de barbeiro ali na praça Rui Barbosa cortar o cabelo e fazer limpeza de pele. Nós dois. Vamos arrancar aquela espinharada dele, vamos arrumar um monte de namorada que a senhora vai ver só. Ele não vai querer ir, porque conheço ele, mas fala para ele largar mão de ser besta (RUFFATO, 2016, p. 109).

Mas as narrativas que essas cartas trazem (nada é mais privado e íntimo que uma carta para a mãe, eis um paradoxo) não se restringem aos problemas individuais de José Célio, o jovem torneiro mecânico que se muda para Diadema, para trabalhar, em busca de uma vida melhor. Se essas cartas adormecidas fermentavam um acerto de contas, tal acerto de contas ultrapassa a dimensão individual do narrador.

Já no alto da primeira carta, encontramos uma data, um lugar, um tempo, um índice histórico: São Paulo, 2 de fevereiro de 1971. Estamos no auge da Ditadura Civil-Militar, que assolou o Brasil e durou de 1964 até a redemocratização, no final dos anos 1980, período cujo legado é um rastro de mortos, desaparecidos: milhares de cadáveres mal enterrados.

Os conflitos vivenciados por José Célio funcionam como uma espécie de metonímia da história brasileira dessa época. Se nas primeiras cartas da personagem as preocupações ficam restritas ao minúsculo universo da família, uma espécie de caipira ingênuo que vai descobrindo a cidade, à medida que a narrativa avança, o personagem sofre o impacto das forças históricas e sociais. José Célio, um sujeito honesto e trabalhador, vai desvelando essa trama maior que ultrapassa seus pequenos sonhos pueris. As tensões da História, já indiciada nas datas, infiltram-se aos poucos na narrativa.

$\mathrm{Na} 12^{\underline{a}}$ carta, datada de 28 de maio de 1972, José Célio diz que havia mandado uma carta no começo do mês, mas "deve ter extraviado. A dona Sinoca falou que acontece muito isso, e até admirou que eu recebo as cartas que a senhora manda tão direitinho" (RUFFATO, 2016, p. 51). É indício de violação de correspondência, prática comum em regimes totalitários. $\mathrm{Na}$ carta de 22 de julho de 1974, depois de um grande hiato, um caso mais grave:

Outro dia, aconteceu um negócio esquisito com um rapaz que mora comigo na pensão, o Norivaldo, um sujeitinho falante, desses meio entrão, sabe? Parece que ele estava andando na rua, o pessoal da cavalaria que tem aqui perto passou, ele fez pouco dos soldados, um deles desceu, mandou ele beijar o cavalo, ele falou que ia beijar coisa nenhuma, eles carregaram ele para a delegacia e deram uma surra danada nele. Parece que o negócio foi feio, porque ele apareceu na pensão todo machucado. Eu não vi não, me contaram, pegou a bolsa dele e 
sumiu. Ninguém mais ouviu falar dele. A gente tem que tomar cuidado com o que a gente fala por aqui. Eu tomo (RUFFATO, 2016, p. 82).

Na carta seguinte, José Célio volta ao caso. Diz que Norivaldo não apareceu nunca mais. "O Fabinho, que é uma pessoa bem informada, falou que o problema é a ditadura, que eles prendem e desaparecem com a pessoa. Também, tem um pessoal que gosta de folia. Eu fico quieto no meu canto. Não me meto com ninguém" (RUFFATO, 2016, p. 84).

$\mathrm{O}$ envolvimento da personagem com as questões políticas perpassa um sentimento de desterro, para depois recair sobre a jornada exaustiva de trabalho, o problema da desigualdade, na esteira da condição do trabalhador e dos problemas sociais. Na carta de janeiro de 1975, ao retornar de mais uma visita à sua cidade natal, ele percebe que nunca mais vai voltar amorar no interior, mas também não se sente em casa em São Paulo: "não sou de lugar nenhum. E isso dói dentro da gente" (RUFFATO, 2016, p. 89). Mais adiante, José Célio vai dizer que entende a revolta do seu amigo Fabinho, que questiona o sentido de que, para ganhar a vida, seja necessário se afastar das pessoas a quem se ama.

Eu penso que nem ele, esse mundo é muito injusto. Aí em Cataguases, quando os filhos desse pessoal rico vão estudar fora, eles sabem que mais dia menos dia voltam e vão ser médico, engenheiro, dono de fábrica, advogado. Mas a gente, que é pobre, sai para nunca mais (RUFFATO, 2016, p. 98).

A tristeza e o incômodo de José Célio não são dramas abstratos, quase metafísicos, como aquele vazio existencial burguês, um "drama universal”. $\mathrm{Na}$ perspectiva da personagem, estão situados concretamente na sua condição social.

Às vezes, Deus que me perdoe, chego a desconfiar que se Deus existe mesmo. Porque às vezes eu fico pensando que se ele existe só protege os ricos. Os pobres ele deixa a deus-dará. Não falo mais, porque a senhora não gosta, acha que é blasfêmia, mas por dentro, não minto para a senhora não, ando cada vez mais revoltado (RUFFATO, 2016, pp. 101-102).

O discurso agora revela uma personagem bem diferente daquele jovem das primeiras cartas, que não fazia outra coisa a não ser trabalhar e ficar quieto no seu canto. A convite de Fabinho, José Célio resolve participar do sindicato. Diz para a mãe não se preocupar, porque não é arruaça, o tal sindicato é ligado à Igreja (RUFFATO, 2016, p. 105). O argumento de Fabinho é que José Célio conta com o respeito da chefia ao mesmo tempo que exerce certa liderança sobre os empregados da firma (p. 113). Esse 
envolvimento com sindicato, contudo, começa a criar problemas para José Célio.

Devo mudar de pensão no começo do ano. Tem um rapaz que mudou para aqui que o pessoal do sindicato me falou que não é para confiar nele não, que ele é dedo-duro da Polícia Federal. Que ele está em Diadema para vigiar a gente e entregar para o governo, porque a senhora sabe que a gente vive debaixo de uma ditadura que prende e mata trabalhadores, que a única coisa que querem é mudar a situação injusta do país, mas a senhora nem fale isso aí em Cataguases não, senão eles ainda prendem a senhora e dizem que a senhora é comunista (RUFFATO, 2016, p. 114).

Se falar do espectro é falar da Justiça (é isso que traz o rei morto ao encontro de Hamlet), não é também por acaso, ou de forma acidental, que os rastros da História se manifestam no romance de Ruffato. Não se trata apenas de um "tema" do passado, de um tema de museu, tampouco de um assunto supostamente engajado, escolhido a esmo, ou da vontade de um sujeito particular em reproduzir um período dito histórico.

Existe uma legião de mortos mal enterrados que nos assombram. Um passado para semprevivo e presente na angústia daqueles que não puderam ao menos sepultar seus filhos, pais, irmãos. Cadáveres sem túmulo, que pairam sobre nossas cabeças. Os rastros dessa Ditadura ainda estão por aí, hoje, agora: "Pois nenhuma palavra melhor do que 'violência' descreve esta maneira que tem o passado ditatorial de permanecer como um fantasma a assombrar e contaminar o presente" (SAFATLE; TELES, 2010, p. 12). Em cada esquina em que um jovem é morto pela ação criminosa da polícia, na chacina de Osasco, ${ }^{5}$ nos dezoito garotos que foram presos de maneira irregular e passaram mais de oito horas isolados, sem direito a advogado, sem poder falar com a imprensa ou com os familiares. ${ }^{6}$ A Ditadura está morta, mas mal enterrada. Emerge como espectro.

Estamos acostumados a ver a História como um conjunto de feitos heroicos, de um processo inexorável de evolução cronológica. Mas História é a história das catástrofes: nos rastros da História, encontramos

5 Cf.: "Ato no Masp lembra um ano da chacina de Osasco". G1. Disponível em: <http:// g1.globo.com/sao-paulo/noticia/2016/o8/ato-no-masp-lembra-um-ano-da-chacina-deosasco.html . Acesso em: 14 set. 2016.

6 Cf.: "Presença de capitão do Exército entre manifestantes presos é investigada". G1. Disponível em: <http://g1.globo.com/sao-paulo/noticia/2016/o9/caso-de-capitaoinfiltrado-entre-manifestantes-e-apurado-pelo-exercito.html>. Acesso em: 14 set. 2016. 
pilhas e pilhas de corpos putrefatos que, caso ressurgissem, inundariam nossas ruas, invadiriam nossas casas.

\begin{abstract}
Onde nós vemos uma cadeia de acontecimentos, ele vê uma catástrofe única, que acumula incansavelmente ruína sobre ruína e as arremessa a seus pés. Ele gostaria de deter-se para acordar os mortos e juntar os fragmentos. Mas uma tempestade sopra do paraíso e prende-se em suas asas com tanta força que o anjo não pode mais fechá-las. Essa tempestade o impele irresistivelmente para o futuro, ao qual ele volta as costas, enquanto o amontoado de ruínas diante dele cresce até os céus (BENJAMIN, 2012, p. 256).
\end{abstract}

Se pudéssemos contemplar, num lampejo, essas ruínas sobre ruínas, que se erguem até os pés do Anjo da História, ali encontraríamos uma legião de espectros errantes, incapazes de descansar. Ecos de vozes silenciadas. Espectros que se manifestam e são mesmo a condição de toda e qualquer possibilidade constituinte daquilo que chamamos tempo presente.

Se no livro de Ruffato o luto é uma questão que envolve o narrador no plano privado, ao evocar esse plano, o livro também evoca um luto público, que é luto na perspectiva da História, da nossa história. Um luto que não pode ser vivenciado por conta da Lei da Anistia. E as tentativas louváveis de trabalhar esse espectro são ainda tímidas, isso quando não são boicotadas, como é o caso da Comissão da Verdade. ${ }^{7}$

Ao final de sua famosa conferência sobre o tema da ficção que se ocupa da história, Fredric Jameson (2007) coloca um dilema. O romance histórico supõe a divisão de dois planos: um plano privado, ou existencial, e um plano público, o plano da história. Mas o que ocorre hoje é uma indiferenciação cada vez maior desses planos: o primeiro motivo é uma noção desenvolvida por Hannah Arendt, da privatização inexorável da vida pública. “Tudo, pensava ela, está sendo atraído para a esfera privada; julgamos os nossos políticos como a qualquer pessoa que encontramos no dia a dia; o político é rebaixado ao nível de uma simples especialização da realidade entre muitas outras" (p. 202). O segundo motivo apontado pelo filósofo é o exato oposto: há lugares no mundo em que as convulsões e catástrofes históricas penetraram tão violentamente no plano existencial

7 "Depois de dois anos de trabalho, 1.045 depoimentos em 73 audiências públicas, os integrantes da Comissão Nacional da Verdade (CVM) mapearam e ajudaram a esclarecer boa parte dos casos de torturas, mortes e ocultação de cadáveres praticados ou comandados por agentes do Estado durante a ditadura militar. No entanto, a três meses da entrega do relatório final, os responsáveis pelas investigações que apuram as denúncias de violações aos direitos humanos se depararam com um obstáculo: a resistência de militares em colaborar com a comissão." (RODRIGUES, 2014).

Remate de Males, Campinas-SP, v. 37 n. 1, pp. 429-447, jan./jun. 2017 
do indivíduo que "a vida cotidiana e existencial se tornou uma longa catástrofe histórica, tornando-se, portanto, impossível qualquer distinção entre os planos, condição necessária ao romance histórico" (p. 202).

O romance de Ruffato, nesse sentido, acaba por superar essa contradição: as cartas íntimas de um jovem, endereçadas à mãe e escritas nos anos 1970, perfuram o tempo e chegam até nós. Se não operam o luto necessário da esfera pública, apontam para esse horizonte problemático: os espectros que nos assombram. ${ }^{8}$

As últimas cartas de José Célio vivem a expectativa política relacionada à atuação do sindicato. $O$ torneiro mecânico celebra as conquistas alcançadas no final de 1977:

Setembro foi um mês complicado para nós. Ninguém falou nada, mas conseguimos mobilizar um mundaréu de gente na nossa campanha pela reposição dos 34,1\%, quer dizer, para repor no nosso salário um índice que o governo roubou do trabalhador. O pessoal do sindicato ficou contente para burro, porque os mais velhos falaram que desde o começo da ditadura não viam coisa assim acontecer por aqui. Agora, vamos preparar para o ano que vem. Está todo mundo animado e já tem gente falando que agora a coisa vai (RUFFATO, 2016, p. 122).

No ano seguinte, 1978, houve uma grande greve dos Metalúrgicos do chamado "ABC paulista" e de Diadema, que culminou na ascensão da figura de Luís Inácio Lula da Silva e na fundação do Partido dos Trabalhadores. ${ }^{9}$ Embora a morte de José Célio ocorra antes das grandes manifestações, ele está conectado com essas questões:

O negócio está pegando fogo. O nosso Primeiro de Maio vai ser uma demonstração de força da categoria. Consegui marcar as férias de 15 de março a 15 de abril, porque quero estar firme na posse do nosso presidente do sindicato, no dia 21 de abril, para participar dos preparativos da nossa festa do Dia do Trabalhador (RUFFATO, 2016, pp. 126-127).

8 Por outro lado, esse romance, na esteira do projeto de Ruffato, está ancorado em uma nova chave realista, um regime ético da imagem: "Trata-se de um realismo preocupado com a origem da imagem criada, sua referência, e nesse sentido salienta a questão da verdade, por um lado, e a de seus usos e efeitos, por outro. A insistência sobre a factualidade do narrado, as referências autobiográficas, os traços documentais recorrentes, a tematização da técnica e do fazer sempre subordinado ao conteúdo a ser depurado pelo escritor, tudo isso abre mão da finalidade literária, do literário enquanto experiência estética, em nome de um desafio e de um compromisso a ser cumprido" (SCHOLLHAMMER, 2016, p. 236). 9 Cf.: "Lula ganha projeção nacional em 1978. PT é fundado dois anos depois". O Globo, 25/o9/13 (Acervo). Disponível em: <http://acervo.oglobo.globo.com/fatos-historicos/ lula-ganha-projecao-nacional-em-1978-pt-fundado-dois-anos-depois-em-sao-paulo10141275\#ixzz4KL1EfVH1>. Acesso em: 15 set. 2016.

Remate de Males, Campinas-SP, v. 37 n. 1, pp. 429-447, jan./jun. 2017 
Essa é a penúltima carta. Na seguinte, José Célio fala dos preparativos da viagem, na qual morre. Em nota de rodapé do narrador (RUFFATO, 2016, p. 128), há o esclarecimento de que a polícia rodoviária informou que provavelmente Célio tenha dormido no volante, o que o levou a bater de frente com o caminhão. ${ }^{10}$

\section{Apêndice: um lamento}

Depois da última carta de Célio, encontramos um apêndice, que é uma carta escrita pelo narrador Luiz Ruffato, datada de 15 de março de 2008, dirigindo-se a Célio (mas fundamentalmente a si mesmo, já que o irmão nunca lerá essa carta). Em relação à cronologia, essa resposta de Ruffato ao irmão quebra um silêncio de cinco anos, já que as cartas teriam sido lidas pelo narrador em 2003. Por que esse grande silêncio? Por que só agora essa resposta?

O motivo apontado pelo narrador vem expresso na carta. Sua irmã telefonou pela manhã lhe informando que fazia trinta anos da morte do irmão. Mas isso não é condição suficiente para explicar essa resposta: Por que não a escreveu quando a morte completou vinte anos? Ou dez anos? Aqui podemos lançar uma hipótese: da mesma forma que há uma certa resistência em enfrentar o passado no plano da História, o narrador Luiz Ruffato também enfrenta essa resistência à sua história pessoal. Isso explica esse silêncio de anos.

É justamente nessa carta de Ruffato ao irmão que encontramos uma resposta àquela frase espectral que aparece na folha de rosto: "Para você, que já me esqueceu". A essa voz espectral Ruffato responde: "Lamento termos convivido tão pouco" (RUFFATO, 2016, p. 133), o que seria uma espécie de mea culpa, que vai culminar na sentença final do livro: "Envelheci, envelhecemos todos... Menos você, que permanece com 26 anos, ardendo inexoravelmente em minhas lembranças" (p. 136).

Por outro lado, é nesse momento que o espectro de José Célio se manifesta e se materializa, no registro fotográfico: "Aquele agosto cristalizou-se numa fotografia, a única em que aparecemos juntos"

10 O leitor pode obviamente especular se o acidente teria sido provocado pelos militares, já que a correspondência de José Célio vinha sendo violada e seu discurso, tomando um caráter subversivo. Fabinho inclusive fez menção ao papel de liderança que José Célio exercia entre funcionários. Outra questão: José Célio cita um companheiro de viagem, que, no entanto, não estava no carro quando ocorreu o acidente. A explicação de Ruffato é a de que o irmão inventou o amigo para tranquilizar a mãe, o que pode ser verdade, ou não. Em todo caso, não há maiores indícios dessa hipótese no texto. 
(RUFFATO, 2016, p. 135). "Na fotografia em que aparecemos juntos, entretanto, o tempo está presente" (p. 136). A fotografia pertence à espectralidade: ela torna visível o que já é passado, o que já morreu (PERRONE-MOISÉS, 2016, p. 155). Há algo de terrível em toda fotografia, nos diz Barthes (1984, p. 20): o retorno de um morto.

\section{A ESCRITA E O TÚMULO: COMO ENTERRAR UM ESPECTRO}

Para finalizar, gostaria de falar da relação da escrita com a morte, naquelas reflexões levantadas por Jeanne-Marie Gagnebin (2014), que podem apontar um caminho para entender essa obra de Ruffato, por aproximarem as noções de passado, morte e espectro.

Segundo a ensaísta, escrevemos sempre em relação íntima com a morte, a dos outros, mas também a nossa. Se fôssemos imortais, não precisaríamos escrever: quando escrevemos, lembramos que morremos (GAGNEBIN, 2014, p. 14). Essa relação da escrita com a morte está presente nos rituais fúnebres, mas também cristalizada nos poemas épicos, como a Odisseia e a Ilíada. O ritual funerário e o canto poético são duas práticas não apenas solidárias, mas semelhantes: "Se o túmulo é um signo (sèma) construído com pedras, o poema também é signo, túmulo (sèma) de palavras; ambos têm por tarefa lembrar aos de amanhã a existência dos mortos de ontem e de hoje" (p. 15).

Ora, se escrever é marcar um passado, em diálogo com os espectros do passado, jamais o homem carregou uma memória histórica tão vasta como a atual, diz Leyla Perrone-Moisés (2016, p. 150), e a memória recente, do século XX, marcada por guerras e catástrofes, é culpabilizante. Nesse sentido, é possível olhar as narrativas de ficção histórica, como é o caso desse livro de Ruffato, como que motivadas por espectros: Espectro da Ditadura, Espectro da Escravidão, Espectro da Colonização, Espectro do Massacre das Nações Indígenas. Diante desse passado que nos assombra nesse agora, as narrativas de ficção histórica são uma tentativa de conjurar esses espectros. Isso porque a palavra é uma espécie de túmulo, e a escrita, como bem apontou Jeanne-Marie Gagnebin (2014, p. 29), é uma espécie de rito de sepultamento:

A escritura da história e a relação do escritor com o passado são ambas práticas de sepultamento, como o afirma Michel de Certeau, que compara as obras dos historiadores aos cemitérios de nossas cidades. Esse "rito de sepultamento" (rite d'enterrent) pode ser interpretado, de maneira clássica, como expressão 
da vontade humana de honrar a memória dos mortos, de respeitar os antepassados, e do opor a fragilidade da existência singular à esperança de sua conservação na memória dos vivos - de reconhecer a dívida que nos liga ao passado, diria Ricoeur. [...] Mas esse rito também permite, como aliás outras práticas de sepultamento e do luto, marcar uma separação clara entre o domínio dos mortos e dos vivos, isto é, impedir que os mortos, invejosos, raivosos, ou somente nostálgicos, possam voltar à luz do nosso (dos vivos) dia.

Como nos diz Michel de Certeau (1982, p. 106), "marcar" um passado é dar um lugar à morte, mas é também "redistribuir o espaço das possibilidades, determinar negativamente aquilo que está por fazer e, consequentemente, utilizar a narratividade, que enterra os mortos, como um meio de estabelecer um lugar para os vivos".

Nessa chave de leitura, fica patente como todo o movimento do narrador do livro de Ruffato é uma tentativa de sepultar o espectro do irmão, que o atormenta: "Aqui reúno esse passado - modo de reparar meus mortos", diz o narrador, "a eles este livro" (RUFFATO, 2016, p. 21). Há o ciúme, já explicado pelo narrador, mas há também uma dívida, porque o irmão mais velho foi fundamental na constituição daquilo que o narrador se tornou: "orgulhosamente me preparava para seguir seus passos" (p. 134).

É para honrar essa dívida que o narrador enfeixa as cartas numa narrativa, e lhe dá o nome livro. Mas é também para erguer um túmulo, onde o espectro possa enfim descansar e libertar Ruffato para seguir adiante. Se a primeira solução parece ter sido alcançada pelo narrador, ao celebrar a memória do irmão, o segundo ponto, apesar do esforço gigantesco, é no fim das contas precário. O espectro continua ali, cristalizado na fotografia. A ferida permanece aberta. Inexorável. Como continuam abertas as chagas da nossa História.

\section{REFERÊNCIAS BIBLIOGRÁFICAS}

BARTHES, Roland. A câmara clara. Nota sobre a fotografia. Trad. Júlio Castañon Guimarães. $9^{\underline{a}}$ imp. Rio de Janeiro: Nova Fronteira, 1984.

BENJAMIN, Walter. Comércio de selos. In: . Rua de mão única. Obras escolhidas III. Trad. Rubens Rodrigues Torres Filho e José Carlos Martins Barbosa. São Paulo: Ed Brasilense, 1987, pp. 57-6o. 
BENJAMIN, Walter. Sobre o conceito de história. In: . Obras escolhidas - I - Magia e técnica, arte e política. 8a ed. rev. Trad. Sérgio Paulo Rounet. São Paulo: Brasiliense, 2012, pp. 241-252.

CERTEAU, Michel de. A escrita da história. Trad. Maria de Lourdes Menezes. Rio de Janeiro: Ed. Forense-Universitária, 1982.

DERRIDA, Jacques. Espectros de Marx: o estado da dívida, o trabalho do luto e a nova Internacional. Trad. Anamaria Skinner. Rio de Janeiro: Relume-Dumará, 1994.

FREITAS, Guilherme. "Cada romance é uma tentativa de reconstruir a história", diz Ruffato (Entrevista). O Globo, 27/03/2016. Disponível em: <http://oglobo.globo. com/cultura/livros/cada-romance-uma-tentativa-de-reconstruir-historia-dizruffato-18960961>. Acesso em: 14 set. 2016.

GAGNEBIN, Jeanne Marie-Gagnebin. Prólogo: escrita, morte, transmissão. In: Limiar, aura e rememoração - ensaios sobre Walter Benjamin. $1^{\mathrm{a}}$ ed. São Paulo: Ed. 34, 2014, pp. 13-30.

JAMESON, Fredric. O romance histórico ainda é possível? Trad. Hugo Mader. Revista Novos Estudos - CEBRAP, São Paulo, no 77, mar. 2007, pp. 185-203.

PERRONE-MOISÉS, Leyla. Espectros da modernidade literária. In: . Mutações da literatura no século XXI. São Paulo: Companhia das Letras, 2016, pp. 149-169.

RODRIGUES, Alan. Boicote dos militares. Isto é, no 2.338, 17/o9/2014. Disponível em: <http://istoe.com.br/382248_BOICOTE+DOS+MILITARES/>. Acesso em: 21 jun. 2017.

RUFFATO, Luiz. De mim já nem se lembra. $2^{\mathrm{a}}$ ed. rev., ampl. e definitiva. São Paulo: Companhia das Letras, 2016.

RUFFATO, Luiz. Um dedo de prosa com Luiz Ruffato (Entrevista - vídeo). [S.d.]. Parte 1. Disponível em: <https://www.youtube.com/watch?v=MJJRpI5XWRY>. Acesso em: 14 set. 2016.

SAFATLE, Vladimir \& TELES, Edson. O que resta da ditadura. São Paulo: Boitempo, 2010. (Coleção Estado de Sítio)

SCHOLLHAMMER, Karl Erik. Fiç̧ão brasileira contemporânea. Rio de Janeiro: Civilização Brasileira, 2009.

SCHOLLHAMMER, Karl Erik. Um mundo de papel - reflexões sobre o realismo de Luiz Ruffato. Alea, v. 18, no 2, 2016, pp. 232-242. Disponível em: <http://dx.doi. org/10.1590/1517-106X/182-232>. Acesso em: 28 abr. 2017.

SHAKESPEARE, William. Hamlet. Trad. Millôr Fernandes. São Paulo: Le PM Pocket, 1997. 
O luto e a história em De mim já nem se lembra, de Luiz Ruffato - 447

SKINNER, Anamaria. Espectros de Marx: por que esse plural. In: NASCIMENTO, Evando \& GLENADEL, Paula (orgs.). Em torno de Jacques Derrida. Rio de Janeiro: 7 Letras, 2000, pp. 65-75. 